\title{
Curriculum and Climate Change Education: Issues and Relevancies in the Nigerian School System
}

\author{
Moyinoluwa, Toyin Dolapo \\ (Nigerian Educational Research and Development Council, (NERDC), Abuja. Nigeria.)
}

\begin{abstract}
Educational system, especially in the developing nations is undergoing fast and tremendous changes. The need for Climate Change Education in the School System cannot be over-emphasized as it is for everyone; such knowledge goes a long way in rationalizing the behavior of individuals throughout their lifetime. Students should be motivated to learn about climate change, and be helped to make links between the various subjects around the issue of the environment of which, obviously, climate change has played a big part. The curriculum makers need to base their work upon the National Policy on Education, Nigeria's Vision 2020 on education and human capital development, and the global trends so that Students will have opportunities for better educational programmes. The paper examines the Curriculum, Climate-Change and its relevance in the School system which contribute to Sustainable Development. This study therefore provides appropriate recommendations geared towards improving Environmental Education in Nigeria.
\end{abstract}

Keywords: Climate Change, Curriculum, Environmental Education, Relevancies, School System

\section{Introduction}

Climate change is one of the most pressing problems facing us today. Our whole future is at stake here, it is extremely important to study climate change in the school system, Students need to see the relevance of a particular academic knowledge before it sinks in. Recent scientific findings indicate that a changing climate has a significant impact on our planet. In 2007, the Intergovernmental Panel on Climate Change (IPCC) issued its Fourth Assessment Report, so far the most convincing assessment on the science and implications of climate change. This report concluded that only immediate and sustained action will stop climate change from causing irreversible and potentially catastrophic damage to our environment. (UNESCO, 2012). The IPCC also noted that climate change will manifest itself in various ways, including:

1) Rising temperatures, droughts and desertification;

2) Heavy precipitation, flooding and rising sea levels;

3) Extreme weather events such as cyclones, floods and droughts.

Such conditions can impact diminishing water resources, causing increased malnutrition, waterborne diseases such as diarrhoea, and vector-borne diseases such as malaria. Floods and rising sea levels can cause drowning, injuries, and severe mental and physical trauma, particularly for communities living in small islands, developing states, settlements alongside major river deltas and low-lying coastal areas. Evidence suggests that developing countries, already struggling with social, economic and environmental issues, will suffer most from greater weather extremes and the increasing incidence of droughts and floods. We must educate the next generation properly about it so that they are able to take the actions that is needed. Learning about climate change will enable students to see the "holistic" nature of knowledge; they will be able to join the dots between the various subject disciplines.

\section{Curriculum}

Curriculum from the Latin word means "the path, the way, and the course", (Collins English Dictionary, 2003); and according to Rugg in Adeyinka (1988), the curriculum is really the entire programme of the schools' work. Curriculum says, "Of all that the students could learn, this is what they must learn, and of all the things we could teach, this is what we must teach". The amorphous nature of the word curriculum has given rise over the years to many interpretations. Depending on their philosophical beliefs, people have expressed their interpretation to be among the following:

- Curriculum is Content.

- Curriculum is a programme of study or a course of study.

- Curriculum is everything that goes on within the school, including extra-class activities guidance and interpersonal relationships.

- Curriculum is a series of experiences undergone by learners in school.

- Curriculum is that which an individual learner experiences as a result of schooling 
Conceptualization of Curriculum and its developmental process, implementation and evaluation are as varied from one philosopher to another; from one educator and/or educationist to another and from one generation to another in time and space. However there is the common understanding that curriculum is a set of planned and organized material designed for an intended learning outcome, considered as adequate for any functional expectations of a people in time and space. There is no doubt that this definition appears simplistic and less inclusive of the many factors that continually present challenges to developers and operators of a given curriculum package. The curriculum makers need to base their work upon the National Policy on Education, Nigeria's Vision 2020 on education and human capital development, and the global trends so that learners will have opportunities for better educational programmes. There is the whole world of differences between the planned and intended curriculum by a state or a nation for each subject area and for the various levels of educational ladder, For example, in Nigeria, The Federal Ministry of Education through its special agencies like CESAC, NERDC, NBTE, N.T.I., etc, have always prepared general curriculum materials for almost all the conceivable subject areas for the primary, secondary and some selected tertiary education programmes.

However, besides this level of curriculum conceptualization and development process, there is the Implemented Curriculum, which is exactly what is being organized and taught at different levels and evaluated by evaluation and certification syndicates or consortia. From all reasonable considerations, it is only when these various conceptualization perspectives are met that the entire education industry would have achieved the objectives embedded in the respective curriculum processes and packages (Okobiah, 2009). Determinants of curriculum can be identified as forces that originate from local, state, national and international levels. Some forces are exerted by either, or both, professional educators and lay people. Some forces originate inside an educational organization, institution or unit (internal), and there are those that come from outside (external). There are four commonly accepted determinants of curriculum. These are:

1. Society, its pressures, needs, laws, events, problems and goals.

2. Knowledge, its nature, structure, organization and new findings.

3. Learning theories and principles.

4. The learner (individual and collective), aspirations, capabilities, past experiences, interests, needs, deficiencies, and developmental requirements.

The world governments have made collective commitment to dramatically expand educational opportunities for children, youths and adults by 2015(UNESCO, 2007). Participants at the World Educational Forum in Dakar, Senegal endorsed a comprehensive vision of education, anchored in human rights, affirming the importance of learning at all ages and emphasizing the need of special measures to reach the poorest, most vulnerable and most disadvantaged groups in society. (UNESCO, 2000). We are in the post-modern generation where children are born and raised in an environment influenced by the internet, and the new revolutions in science, philosophy and communications in all areas of life. There is a shift towards the affirmation of new values.

Science says we live in an expanding universe and we increasingly communicate through visual and symbolic means. These shifts are resulting in a whole new culture and raise new questions about the way curriculum is to be understood, developed, revised and communicated. It is important therefore to address the following issues. Beckner in (Okobiah, 2009) observes that the most important forces acting to change the society today emanate directly or indirectly from the discoveries and the changes resulting from the scientific and technological advancement of the last and present centuries. These include, naming only a few, nuclear and atomic physics, space explorations, electronics, cybernetics, the development of synthetics and medical advancements. All these acting integrally have profound on the school curriculum and development processes.

\section{Climate Change}

Climate change is a significant and lasting change in the statistical distribution of weather patterns over periods ranging from decades to millions of years. It may be a change in average weather conditions or the distribution of events around that average (e.g., more or fewer extreme weather events). Climate change may be limited to a specific region or may occur across the whole Earth. Anyadike (2009) points out that a situation in which a change continues in one direction at a rapid rate and for an unusually long period of time is known as climate change. The most general definition of Climate Change is a change in the statistical properties of the climate system when considered over long periods of time, regardless of cause. The term sometimes is used to refer specifically to climate change caused by human activity as opposed to changes in climate that may have resulted as part of Earth's natural processes. In this latter sense, used especially in the context of environmental policy, Climate change refers to only the changes in modern climate, including the rise and in average surface temperature known as global warming (UNFCCC, 2004), the term climate change today is synonymous with anthropogenic global warming. Within scientific journals, however, global warming refers to surface temperature increases, while climate change includes global warming and everything else that increasing greenhouse gas amounts will affect. 


\subsection{Causes of Climate Change}

\subsubsection{Natural Phenomena}

Climate changes are response to changes in the global energy balance. On the broadest scale, the rate at which energy is received from the sun and the rate at which it is lost to space determine the equilibrium temperature and climate of Earth. This energy is then distributed around the globe by winds, ocean currents and other mechanisms to affect the climates of different regions. Factors that can shape climate are called climate forcings or "forcing mechanisms". These includes such processes as variations in solar radiation, deviations in Earth's orbit, mountain-building and continental drift, and changes in greenhouse gas concentrations. There are a variety of climate change feedbacks that can either amplify or diminish the initial forcing. Some parts of the climate system, such as the oceans and ice caps, respond slowly in reaction to climate forcings, while others respond more quickly.

Forcing mechanisms can either be "internal" or "external". Internal forcing mechanisms are natural processes within the climate system itself (e.g., the meridional overturning circulation). External forcing mechanisms can either be natural (e.g., changes in solar output) or anthropogenic (e.g., increased emissions of greenhouse gases). Whether the initial forcing mechanism is internal or external, the response of the climate system might be fast (e.g., a sudden cooling due to airborne volcanic ash reflecting sunlight), slow (e.g., thermal expansion of warming ocean water), or a combination (e.g., sudden loss of albedo in the arctic ocean as sea ice melts, followed by more gradual thermal expansion of water). Therefore, the climate system can respond abruptly, but the full response to forcing mechanisms might not be fully developed for centuries or even longer.

\subsubsection{Human Influences}

In the context of climate variation, anthropogenic factors are human activities which affect the climate. The scientific consensus on climate is "that climate is changing and that climate is changing and that these changes are in large part caused by human activities, and it is largely irreversible. According to the Wikipedia free encyclopedia (2011) "science has made enormous inroads in understanding climate change and its cause, and is beginning to help develop a strong understanding of current and potential impacts that will affect people today and in coming decades. This understanding is crucial because it allows decision makers to place climate change in the context of other large challenges facing the nation and the world;'”

The Earth is getting warmer because people are adding heat trapping gases to the atmosphere; mainly by burning fossil fuels these gases are called greenhouse gases. Warmer temperatures are causing other changes around the world, such as meeting glaciers and stronger storms. These changes are happening because the Earth's air water and land are all linked to the climate. The Earth's climate has changed before, but this time is different people are causing these changes, which are bigger and happening faster than any climate changes that modern society has ever seen before of most concern in these anthropogenic factors is the increase in carbondioxide $\left(\mathrm{CO}_{2}\right)$ levels due to emissions from fossil fuel combustion, followed by aerosols (particulate matter in the atmosphere) and cement manufacture.

Other factors including land use, ozone depletion, animal agriculture and deforestation are also of concern in the roles they play - both separately and in conjunction with other factors - in affecting climate, micro climate and measures of climate variables physical evidence for and examples of climate change: These are taken from a variety of sources that can be used to reconstruct past climates reasonably complete global records of surface temperature are available from the mid-late $19^{\text {th }}$ century these include:

- Temperature measurement and proxies

- Historical and archaeological evidence

- Glacier

- Arctic sea ice loss

- Vegetation

- Precipitation

- Dendron climatology

- Ice cores

- Animals

- Sea level change current seal level rise, etc

\section{Relevancies of Climate Change in the School System}

Climate change is an environmental issue, therefore Environmental Education (EE) which according to Shrivastava, (2006), is the process of providing learning experiences to obtain the knowledge, understanding, skills and awareness with the desirable attitudinal changes about man's relationship with natural and man-made surroundings, stands the appropriate tool for exposing the individual into the awareness of what the environment he has to interact with is, and also, how to explore and still protect the environment in order to avert the existing environmental problem which has left the world over with sleepless night. 
Apel \& Comazzi (1999) stress that environmental education alone is not an instrument for saving the world but more of an instrument for strengthening those entering the arena in the quest for a more sustainable co-operation between humankind and nature; and must be used as a tool of change. Success in addressing the challenge of climate change depends on all countries meeting their international commitments and obligations in accordance with their common but differentiated responsibilities and capabilities. Enger \& Smith (2004). They stress that upgrading research, development, application, diffusion and use of cleaner fossil fuel technology renewal resources of energy is essential. It is also necessary for universities and teacher training institutions to offer environmental education for pre- and in- service teachers to enable them become knowledgeable and have the understanding of environmental issue and interact sustainably with the environment.

The importance of Environmental Education in the School System cannot be over-emphasized as it is for everyone; such knowledge goes a long way in rationalizing the behavior of individuals throughout their lifetime. Students are really motivated to learn about climate change, there has been a drive to help pupils make links between the various subjects around the issue of the environment and, obviously, climate change has played a big part in that. A classic and highly regarded definition of sound environmental education maintain that environmental education goes beyond the mere importing of information to provide: a working knowledge of environmental issues; specific knowledge approaches to address those issues; the ability of certain affective quality (attitude).

Education in the environment helps people develop sensitivity to their surroundings and the natural world. Education about the environment promotes understanding of the natural, physical and social systems that make up our environment. Education for the environment motivates people to work to improve the environment (Roth, Cambell and Bousquent, 1980 in Ohio Environmental Education, 2000). Regardless of the words we use, several core characteristics of environmental education, when taken together, help define environmental education as an endeavour :

$>$ Environmental education relates to an environmental topic or issues showing in clear connections to environment and environmental concerns.

$>$ Environmental education is interdisciplinary, drawing upon many fields of study and learning; involve integrated thematic or interdisciplinary approach with unifying themes and big ideas.

$>$ Environmental education is relevant to needs, interest and motivations of learner relating learning to the real world, relevant to the learners and encompasses issues important to society.

$>$ Environmental education is a lifelong learning process, environmental education content should equip learners with necessary skills to continue learning throughout life;

$>$ Environmental education is based on accurate and factual information. Content should be based on accurate, reliable and credible information.

$>$ Environmental education presents information in a balanced and unbiased manner. Environmental education content should be balance and unbiased and should consider differing values and points of view.

$>$ Environmental education makes use of the outdoors as a learning environment whenever possible and appropriate. Environmental education content should when appropriate emphasize knowledge of comfort with and sensitivity to natural world.

$>$ Climate change is one of the most pressing problems facing us today. We must educate the next generation properly about it so that they are able to take the actions that is needed. Our whole future is at stake here, It is extremely important to study climate change in the school system.

\section{Conclusion}

Environmental education has a lot to play in creating awareness on climate change. In the first place it provides the human race with knowledge and understanding about the usefulness of a sustainable environment and what to do to sustain the environment in order to have a legacy for the generations yet unborn; and how to curb the problem or challenges the world is facing through the effect of climate change. It has been postulated that knowledge doubles itself in every decade and perhaps less than a decade in the $20^{\text {th }}$ and $21^{\text {st }}$ centuries. The schools and the related educational institutions have the responsibilities of passing on the ever-changing knowledge strides from on generation to the succeeding generations. It is not a simple task and responsibility. However, in the new global world of information and knowledge explosion, it is the responsibility of the school to provide the skills of understanding and utilization of knowledge rather than accumulation of knowledge.

The new approach is to see education as primarily a process by which the individual learner is provided with skills to organize his knowledge and to increasingly become more functionally to efficienct in all his or her intellectual and service delivery efforts. Here is where ICT is of the uppermost efficiency tool for the acquisition of such skills within the shortest possible pace by the individual. Climate change is a global challenge for the curriculum developers and the implementers alike. Teaching climate change is essential, because its one of the biggest threat facing our planet today and its seams it is not being taken serious. Including the teaching in the school system would be one of the best things to do to safe our universe. 
Given the complex, emergent, historic and context nature of climatic and environmental problems and issues in Nigeria that require highly technical skills to correct and improve environmental sustainability and the low level of literacy and environmental literacy which is reflected in the environmental awareness of the citizenry a paradigm shift to promote environmental sustainable development for now and the future generations is a global drive that Nigeria cannot be left behind. Students have definitely benefited from applying theory to practical examples. The most obvious instance of this is in science, where pupils learn the theory and science of the greenhouse effect and then experience the real-life examples. Students need to see the relevance of a particular academic knowledge before it sinks in. Learning about climate change will enable students to see the "holistic" nature of knowledge; they will be able to join the dots between the various subject disciplines.

Most importantly, climate change is one of the most pressing problems facing us today. We must educate the next generation properly about it so that they are able to take the actions that is needed. Our whole future is at stake here, it is extremely important to study climate change in the school system. The issue of climate change and sustainable development has attracted global attention. As the world strives to attain the Millennium Development Goals (MMDGs) by the year 2015, it may be necessary to increase the content of climate change and sustainable development in the school curriculum particularly at the Basic and Secondary School levels. Since they fall short, there is the urgent need to add to the learning experiences as well as identifying new teaching methods and pedagogies and structures suitable for building the necessary capacities for climate change and sustainable development. The awareness of the effects of climate change will help all students including persons with special educational needs and disabilities to develop positive attitude towards their environment.

\section{Recommendations towards Improving Climate Change Education in Nigeria}

Governments should take action at regional, national, and local levels, including:

- Translating international agreements into domestic policy

- Multidisciplinary model curriculum (infusion) may be appropriate for primary and junior secondary school (Basic Education) as it is presently practiced. There is need for curricula review to accommodate frontline environmental issues and problems with adequate textual materials and environmental education resources to enhance meaningful learning and teaching. The onus is on the Curriculum Development Centre (CDC) of the Nigerian Educational Research and Development Council (NERDC) to as a matter of urgency include topics on climate change and sustainable development in the Basic and Secondary School syllabi in relevant disciplines.

- Senior Secondary level as well as tertiary institution interdisciplinary approach to environmental education will provide adequate ground for environmental literacy through outdoor environmental education programmes and activities to promote problem solving, ethical attitude and behavioural development toward environmental sustainable practices.

- Develop inter-sectoral partnership between all stakeholders: Federal Ministry of Education, Federal Ministry of Environmental, National Emergency Management Agency, Federal Environmental Protection Agency, National Environmental Standards and Regulations Enforcement Agency and other MGOs such as National Conservation Foundation and Science Teachers Association of Nigeria etc. should be developed to produce synergy in developing environmental literacy programmes for formal, non-formal and informal education in environmental education as the case of US, Australia etc.

[1] Intergovernmental Panel on Climate Change, Climate Change: The physical science basis-Fourth Assessment Report (IPCC, Geneva,2007)<www.ipcc.ch/publications_and_data/publications_ipcc_fourth_assessment_report_wg1_report_ the_physical_science_basis.htm>, accessed 11 March 2012.

[2] UNESCO, Climate Change and Environmental Education written by Selim Iltus.( New York. UNESCO, 2012).

[3] Collins English Dictionary (- Complete and Unabridged @ HarperCollins, 2003)

[4] Adeyinka, A. A., Major Trends in Curriculum Development in Nigeria, Ilorin Journal of Education, Vol. 8, Sept 1988. 9-19.

[5] Okobiah O. S., Curriculum and Global Challenge, A keynote Address delivered at the $22^{\text {nd }}$ Annual conference of the Curriculum Organization of Nigeria at the Delta State College of Education, Agbor, in September, 2009.

[6] UNESCO, Education for all by 2015: Will we make it? ( Paris. UNESCO, 2007).

[7] UNESCO, The Dakar framework for action education for all: meeting our collective commitments.(Darka: UNESCO, 2000).

[8] Anyadike R.N.C, Climate Change and Sustainable Development in Nigeria: Conceptual and Empirical Issues; Enugu: African Institute for Applied Economics, 2009).

[9] UNFCCC, United Nations Framework Convention on Climate Change. The First Ten Years. (Produced by the Information Services of the UNFCCC secretariat. Halesworth: Technographic Design and Print Ltd, 2004).

[10] Wikipedia free encyclopedia (2011). Downloaded from the internet -20-04-13.

[11] Shrivastava, K.K., Environmental Education: Principles, Concepts and Management, (Kanishka Publishers, Distributors, New Delhi, 2006).

[12] Apel,H. and Comazi, A.,Adult Environmental Education: A handbook on Context and Methods. Institute for International Cooperation of the German Adult Education Association; German, DVV, NO.47, 1999).

[13] Enger E.D. and Smith B. F., Environmental Science: A Study of Interrelationships, Tenth Edition; ( Mc Graw-Hill Companies Inc. New York, 2006).

[14] Ohio Environmental Education, Preservice Teacher Education: A Research Report,( Ohio,2000).

www.iosrjournals.org $\quad 25 \mid$ Page

